\title{
Temperature-dependent visitation rates of bumblebees to different colour-morphs of Geranium sylvaticum (Linnaeus, 1753)
}

\author{
Частота посещения шмелями разАичных цветовых морф \\ соџветий герани Geranium sylvaticum (Linnaeus, 1753) \\ в зависимости от температуры
}

\author{
C.D. Soulsbury*, S. Varga*,** \\ K.A. Солсбери*, C. Варга*,**
}

\begin{abstract}
* School of Life Sciences, University of Lincoln, Lincoln LN6 7TS United Kingdom. E-mail: csoulsbury@lincoln.ac.uk.
* Отделение наук о жизни, университет Линкольна, Линкольн LN6 7TS Великобритания.

** Department of Biological and Environmental Science, University of Jyväskylä, P.O. Box 35, Jyväskylä 40014 Finland.

** Отделение биологических и экологических наук, университет Йювяскюля, Йювяскюля 40014 Финляндия.
\end{abstract}

Key words: Bombus terrestris, colour polymorphism, gynodioecy, temperature.

Ключевые слова: Bombus terrestris, цветовой полиморфизм, гинодиэция, температура.

\begin{abstract}
Both temperature and flower colour have major effects on the foraging of pollinators. Despite both factors being important, no studies have examined the interactive effects of temperature and colour and how this may impact the maintenance of natural floral colour polymorphisms. We tested how temperature influenced bumblebees (Bombus spp.) visitation rates to Geranium sylvaticum (Linnaeus 1753) plants both in a greenhouse and field settings. G. sylvaticum shows colour polymorphism among populations, and individuals can be classified into two discrete morphs, dark morphs or pale morphs based on their visible light. We found that bumblebee visitation rates to plants and flowers increased linearly with temperature in the greenhouse and in the field, before decreasing at the highest temperatures in the greenhouse. In the greenhouse, there was an increasing preference for dark morphs at $23-26{ }^{\circ} \mathrm{C}$, whereas dark morphs received more visits than pale morphs at all temperatures. Temperature-related differences in reward quality along with differences between colour morphs are likely to drive this pattern, though other mechanisms could be important.
\end{abstract}

Резюме. Как температура, так и окраска цветов оказывают большое влияние на присутствие опылителей. Несмотря на то, что оба фактора в равной мере важны, ни одного исследования взаимозависимости температуры и окраски цветков и того, как это может повлиять на поддержание естественного цветового полиморфизма соцветий, не было опубликовано. Мы проверили, как температура влияет на посещаемость шмелями (Bombus spp.) растений Geranium sylvaticum (Linnaeus, 1753) как в теплице, так и в полевых условиях. В популяциях G. sylvaticum прослеживается полиморфизм окраски, и растения можно разделить на две дискретные морфы с тёмными и бледными цветками. Мы обнаружили, что частота посещения шмелями цветущих растений линейно возрастала с повышением температуры в теплице и в поле вплоть до момента снижения посещаемости при достижении максимальных температур в теплице. В теплице отмечено максимальное посещение тёмноокрашенных цветков при температуре $23-26^{\circ} \mathrm{C}$, хотя именно тёмнокрашенные морфы более часто посещались шмелями по сравнению с бледноокрашенными при любых значениях температуры. Зависимость посещения шмелями соцветий герани от различной температуры и конкретной окраски цветков, вероятно, является определяющим фактором выбора, хотя и другие механизмы также могут оказывать значительное влияние на предпочтения опылителей.

\section{Introduction}

Floral characters such as colour, odour and flower shape have major influences on the attractiveness of flowers to pollinators [Willmer, 2011]. Colour in particular is the most important method of attracting pollinators [Kevan et al., 1996] and is incredibly plastic across the angiosperms [Rausher, 2008]. In some species, flower colour polymorphism (the existence of multiple discrete flower colour phenotypes in a single species) can occur [see Warren and McKenzie, 2001 for the distribution of flower colour variation in the British Flora]. Colour polymorphism can arise due to changes in the regulation of pigment biosynthesis [e.g. Durbin et al., 2003] or by mutations in the enzymes themselves [e.g. Quattrocchio et al., 1999]. The maintenance of colour polymorphism has been mainly ascribed to disruptive selection or frequency-dependent selection exerted by pollinators, herbivores and pathogens [Gigord et al., 2001; Irwin et al., 2003; Frey, 2004; Strauss, Whittall, 2007] even though abiotic factors may also contribute to this maintenance through pleiotropic effects [Schemske, Bierzychudek, 2001, 2007; Warren, Mackenzie, 2001; Arista et al., 2013] given the link of flower pigments and biochemically related compounds [Gould, 2004]. Moreover, colour polymorphism may be also a result of flower adaptation to UV light at lower altitudes because floral pigments can help to protect gametes against negative effects of UV [Koski, Ashman, 2015]. 
Insect pollinators show innate preferences for certain colour morphs [Giurfa et al., 1995; Lunau, Maier, 1995]. In addition, most insect pollinators can learn to discriminate among flowers based on the different amount of rewards offered such as nectar [Cnaani et al., 2006], pollen [Kitaoka, Nieh, 2009] or even warmth [Dyer et al., 2006]. Given the relationship between flower constancy and colour [Chittka et al., 1999] and that floral constancy increases foraging efficiency [Gegear, 2005], directional selection towards the most rewarding colour morph should be observed in colour polymorphic plants [Waser, Price, 1983]. However, whether this relationship is affected by temperature is a relatively overlooked factor. Clearly, in cold environments higher temperatures achieved by darker flower morphs may be advantageous for pollen and seed development [Elgersma et al., 1989; McKee, Richards, 1998]. Dark flowers can influence pollinator choice regardless of the amount of nectar offered [Dyer et al., 2006; Nicolson et al., 2013]. However, some works have shown that paler morphs may be warmer. In the colour polymorphic alpine annual Gentiana leucomelaena (Maximowicz et Kusnezow 1892), pale morphs were warmer and opened earlier in the flowering season than darker morphs $[\mathrm{Mu}$ et al., 2010]. Nonetheless, as predicted from innate preferences, dark morphs were preferred by specialist hymenopteran pollinators [Mu et al., 2011]. In addition, the quantity and quality of nectar award is likely critical. Nectar secretion is often positively correlated with temperature [Jakobsen, Kristjansson, 1994] and studies have also shown that certain colour morphs have greater sugar concentrations [e.g. Varga, Soulsbury, 2017]. Thus, both temperature and reward can combine to increase preference for certain colours at increasing temperatures.

In the present study, we investigated bumblebees' response to colour polymorphism using Geranium sylvaticum L. (Geraniaceae), a gynodioecious perennial plant found in boreal-montane areas across Eurasia [Hulten, Fries, 1986]. In G. sylvaticum, colour polymorphism among populations has been reported, with plants producing flowers of a wide range of different colours ranging from white through to dark purple [Vaarama, Jaaskelainen, 1967]. However, all flowers can be distinctly categorised into visible light pale morph (whitepink, non-UV reflective) and visible light dark morphs (violet -purple, UV-bullseye) [Varga, Soulsbury, 2017]. The frequency of the two colour morphs is believed to vary clinally; in southern parts of Finland, dark morphs seemed more frequent whereas in northern parts pale morphs were more common [Vaarama, Jaaskelainen, 1967]. However, both colour morphs can be found together in most locations and there seems to be no relationship between colour and petal size or sexual type of flower [Vaarama, Jaaskelainen, 1967], which is constant within plant individuals.

Bumblebees [Bombus spp.] are important pollinators of G. sylvaticum [Varga, Kytoviita, 2010]. In our study, we focused on Bombus terrestris Linnaeus 1758.
(Hymenoptera: Apidae), a commonly used model species in pollination studies. Bumblebees, including $B$. terrestris, have been shown to have innate preferences for violet-coloured flowers [Gumbert, 2000] and to prefer warmer flowers in experiments using artificial flowers [Dyer et al., 2006]. Like other bees, bumblebees are UVblue-green trichromats and can thus see UV light [Peitsch et al., 1992; Chittka, Wells, 2004]. In G. sylvaticum, dark flowers have higher sugar concentrations, which is temperature-dependent [Varga, Soulsbury, 2017]. Because of the known innate preferences for violet-coloured flowers and for higher sugar concentrations, we hypothesised that bumblebees would visit more dark flowers as temperature increases.

\section{Materials and methods}

Colour categorisation. There are multiple colour morphs in G. sylvaticum populations [Vaarama, Jaaskelainen, 1967]. Under UV, G. sylvaticum flowers can be distinctly categorised into non-UV reflective (referred to pale morphs hereafter and UV reflective with a UV absorbing bullseye (referred to dark morphs hereafter [Varga, Soulsbury, 2017]). Therefore, to characterise flower colour, we collected flowers of the four commonest visible colour types (pale-pink to pink and purple to purple-violet) and took UV photographs. Flowers were mounted against a white paper background and photographed with a Nikon D40x fitted with a Nikon 28-mm series E lens equipped with a reverse-mounted 2-in Baader U-Filter (Baader Planetarium, Mammendorf, Germany). The UV filter removes visible and infrared wavelengths but transmits UV light between 320 and $380 \mathrm{~nm}$, with peak transmission at $340 \mathrm{~nm}$. We illuminated the image field with a UV lamp with peak UV emission at 360-380 ๆm.

Greenhouse experimental set up. Colour preferences were tested using a greenhouse study, carried out in Konnevesi Research Station, central Finland, during 19-th to 26-th June 2012. We use 12 colonies of captive bred $B$. terrestris L. (acquired from Schetelig Oy, Finland), containing approximately 50 workers. Colonies were kept in darkness until used. Bumblebees were naive to flowers prior to experiment. Bumblebees were allowed to forage over 18 single-coloured (9 x dark morph/ $9 \times$ pale morph) bunches of flowers placed standing on pots mimicking natural positions of flowers, containing on average $11.7 \pm 0.1$ open flowers (range: 5-22 flowers). There was no significant difference in number of open flowers between colours (2-sample $\mathrm{t}$ test: $\mathrm{t}_{645}=1.22, \mathrm{P}=0.226$ ); in total, we used 7545 flowers. The pots were placed on a $30 \mathrm{~cm}$ high flat surface, distributed in 3 rows with 6 pots each, at $40 \mathrm{~cm}$ interpots distances and exposed to natural sunlight only. Each day fresh floral shoots from $>50$ plants were collected from the surrounding area and placed immediately in water and used quickly to minimise changes caused by being placed in water. The position of pale/dark morphs were alternately placed and randomised in each 
trial. Each colony was allowed to forage for 30 minutes and the foraging was filmed using a video camera placed to the side of the flowers. The number of visits to individual bunches and the total number of flowers visited were recorded for each trial. After each trial, bumblebees were caught are returned to the hive. Colonies were used for 3 consecutive trials on the same day. Trials were carried out from 09:00 to 18:00. Light and ambient temperature were measured every 10 minutes and the three readings averaged.

We chose to create a scenario that was ecologically realistic. We therefore used real flowers as opposed to artificial ones, which contained naturally varying volumes of nectar, flower and insect odours, and which may have been visited previously by pollinating insects. Plants and flowers in G. sylvaticum also vary in their position in the wild and our placement of flowers in water presented flowers in multiple ways, though in practise this made no difference to bee foraging. All these factors add considerable variance to our data, but at the same time present a real scenario that bumblebees will face in the field.

Field observations: Insect visits to the two colour morphs. Observations were also carried out in the field on a total of 135 plants, which comprised 2901 flowers during June 2012 and June 2013 at four sites in Central Finland where $G$. sylvaticum occurred as an abundant plant. Proportion of dark morphs was $43 \%, 35.8 \%$, $87.8 \%$ and $60.4 \%$ at each site. Observations were carried out from 9:30 to 20:00. Randomly chosen plants were observed for 15 minutes and the number of visits and the insect type (bumblebees, other bees, Diptera and others) visiting the plants were recorded, as well as the number of open flowers and the colour morph noted. Ambient air temperature was also recorded at the start of each observation. In addition, flower and leaf (the closest, fully expanded leaf to the flower) temperatures were measured with a laser infrared thermometer in a subset of plants.

Statistical methods. We first tested whether light level (lux and temperature) in the greenhouse were correlated using Pearson's correlation. We then analysed bumblebee visits in the greenhouse using a generalised linear mixed effects model with a Poisson distribution. The dependent variable was either number of visits to single bunches (hereafter pots) or the total number of flowers visited per pot. We first fitted the polynomial (linear and quadratic) effect of ambient temperature and its interaction with colour. Number of flowers in each pot was included as a fixed factor, and both colony and trial nested within colony, were included as random effects. We tested for both zero inflation and overdispersion prior to data analysis; data were not zero inflated, but were found to be overdispersed so an individual-level random effect was included to account for overdispersion. We then modelled the effect of light (linear only), colour, number of open flowers and their interactions on bumblebee visits to plants and flowers. For both models, we initially include the interaction between ambient temperature (or light) and colour, but if not significant, we reran the model without the interaction. Field data on bumblebee visitations were also overdispersed, but not zero inflated. We used negative binomial models, and like the greenhouse models, the polynomial effect (linear and quadratic) of ambient temperature, number of open flowers and colour were included. The interaction between colour and ambient temperature was initially included, and then removed if non-significant. The relationship between flower and leaf temperature was investigated with an ANCOVA. All models were run using the lmerTest package [Kuznetsova et al., 2014] and MASS package [Venables, Ripley, 2002] in R [R-Core Team, 2015].

\section{Results}

Bumblebee visits in the greenhouse. During the 18 hours of observations the ambient air temperatures registered in the greenhouse ranged between 16 and $33^{\circ} \mathrm{C}$ (with a mean of $24^{\circ} \mathrm{C}$ ) and the light levels ranged between 3 and 142 Klux (with a mean value of 32 Klux). Unsurprisingly, these two factors were strongly correlated $\left(r_{p}=0.59, P=0.04\right)$. Altogether, 767 visits to the pots were observed and in total, the bumblebees visited 2454 flowers.

There was a significant quadratic relationship between temperature and both the number of pots visited and the number of flowers visited (Table 1; Fig. 1a, b). In addition, there was a significant interaction between temperature and flower colour (Table 1); there was a greater number of visits to pot and flowers of the dark morphs between $23-26^{\circ} \mathrm{C}$. Pale morphs were preferred at lower $\left(20-23{ }^{\circ} \mathrm{C}\right)$ and higher temperatures $\left(26-30{ }^{\circ} \mathrm{C}\right.$ Fig. 2a, b). The number of open flowers did not affect the number of visits to pots, but was positively correlated with the number of flowers visited (Table 1; Fig 3). Light level was not associated with the number of pots or flowers visited (Table 1).

Insect visits in the field. During the 20.75 hours of observations, 108 plants were observed and 273 insect visits to 504 flowers were recorded. Registered temperatures ranged between 14 and $27^{\circ} \mathrm{C}$, with an average of $20^{\circ} \mathrm{C}$. Most of the insects visiting $G$. sylvaticum plants were Diptera (58\% of the total visits), followed by bumblebees (14\%), other Hymenoptera (13\%), and bees $(11 \%)$. Moreover, 12 visits were made by beetles and 6 butterflies were observed visiting the plants.

For bumblebees, there was no effect of colour or the number of open flowers on the number of plants visited, but bumblebees visited more plants when it was warmer (Table 2). There was an effect of temperature and colour on the number of flowers visited (Table 2). More flowers were visited when it was warmer, and there was a preference for dark morph flowers at all temperatures (Fig. 4). In addition, the number of flowers visited was positively correlated to the number of open flowers (Table 2). 
Table 1. Results for GLMM between temperature and light (Klux) and the number of visits to pots and to individual flowers in the two different colour morphs of Geranium sylvaticum plants by Bombus terrestris in the greenhouse. Significant results are shown in bold

Таблица 1. Результаты Аля GLMM межАу температурой и освещённостью (Klux), количеством посещений шмемями Bombus terrestris горшков и отдельных цветков двух вариантов окраски соџветий герани в теплице. Значимые результаты выделены жирным шрифтом

\begin{tabular}{|c|c|c|c|c|c|c|c|}
\hline \multirow{2}{*}{ Model } & \multirow{2}{*}{ Factor } & \multicolumn{3}{|c|}{ Number of visits to pots } & \multicolumn{3}{|c|}{ Number of visits to individual flowers } \\
\hline & & $\beta \pm S E$ & $z$ & $P$ & $\beta \pm S E$ & $z$ & $P$ \\
\hline \multirow[t]{7}{*}{ Temperature } & Intercept & $-46.98 \pm 20.98$ & -2.24 & 0.025 & $-56.68 \pm 26.78$ & -2.12 & 0.025 \\
\hline & Temperature [linear] & $3.54 \pm 1.66$ & 2.14 & 0.033 & $4.27 \pm 2.12$ & 2.02 & 0.033 \\
\hline & Temperature [quadratic] & $-0.07 \pm 0.03$ & -2.08 & 0.037 & $-0.08 \pm 0.04$ & -1.97 & 0.037 \\
\hline & Colour & $-20.94 \pm 2.97$ & -7.06 & $<0.001$ & $-24.17 \pm 8.36$ & -2.89 & $<0.001$ \\
\hline & Number open flowers & $0.01 \pm 0.02$ & 0.74 & 0.461 & $0.07 \pm 0.03$ & 2.25 & 0.461 \\
\hline & Temperature [linear] $\times$ Colour & $1.68 \pm 0.24$ & 7.15 & $<0.001$ & $1.91 \pm 0.67$ & 2.85 & $<0.001$ \\
\hline & Temperature [quadratic] $\times$ Colour & $-0.03 \pm 0.00$ & -7.19 & $<0.001$ & $-0.04 \pm 0.01$ & -2.82 & $<0.001$ \\
\hline \multirow[t]{4}{*}{ Light } & Intercept & $-1.81 \pm 0.66$ & -2.74 & 0.006 & $-2.38 \pm 0.89$ & -2.67 & 0.008 \\
\hline & Lux [linear] & $0.01 \pm 0.01$ & 0.76 & 0.449 & $0.01 \pm 0.02$ & 0.82 & 0.415 \\
\hline & Colour & $-0.10 \pm 0.07$ & -1.32 & 0.188 & $-0.14 \pm 0.11$ & -1.32 & 0.188 \\
\hline & Number open flowers & $0.00 \pm 0.02$ & 0.24 & 0.813 & $0.06 \pm 0.03$ & 2.03 & 0.043 \\
\hline
\end{tabular}

Flower temperature. Flower temperature in the field $(\mathrm{N}=101)$ was positively related to leaf temperature $(\beta \pm \mathrm{SE}=0.97 \pm 0.02, \mathrm{t}=52.80, \mathrm{P}<0.001 ;$ Fig. 5a) and not to flower colour $(\beta \pm \mathrm{SE}=0.23 \pm 0.19, \mathrm{t}=1.19, \mathrm{P}=0.237)$. However, diagnostic tests showed two outliers. Removal of these points did not alter the relationship between floral temperature and leaf temperature $(\beta \pm \mathrm{SE}=0.97 \pm 0.02, \mathrm{t}=60.14, \mathrm{P}<0.001)$, but dark flowers were then found to be $0.4^{\circ} \mathrm{C}$ warmer that pale flowers $(\beta \pm S E=0.37 \pm 0.17, t=2.12, P=0.037$; Fig. 5b).

\section{Discussion}

Temperature-dependent bumblebee foraging rates. Our data show that the visitations to both colour morphs were related to temperature; visitation rates increased with temperature before declining at highest temperatures in the greenhouse. Temperature is one of the most important drivers of bee foraging patterns in general [Willmer, Stone, 2004]. Bumblebees have thermoregulatory abilities [Heinrich, 1979; Goulson, 2010] and thus, they are less dependent on climate for carrying out activities that other insects. Field data support this, with $B$. terrestris foraging rates apparently indifferent to irradiance, relative humidity and temperature [Herrera, 1995, temperature range observed not given; Peat, Goulson, 2005, temperature range observed: 13$29{ }^{\circ} \mathrm{C}$ ]. Moreover, similar or even higher foraging rates to those found during summer have been reported for B. terrestris at ambient temperatures as low as $3{ }^{\circ} \mathrm{C}$ [Stelzer et al., 2010]. However, a positive correlation between foraging and temperature like the ones observed in the present study has also been previously shown in B. terrestris [Corbett et al., 1993; Roman,

Table 2. Negative binomial GLM model outputs for number of plants and number of Geranium sylvaticum flowers visited by bumblebees in relation to temperature and flower colour in the field. Significant results are shown in bold

Таблица 2. Результаты отрицательной биномиальной GLM-модели для количества растений и количества џветков Geranium sylvaticum, посещённых шмемями в зависимости от значений температуры и окраски цветов в поле. Значимые результаты выделены жирным шрифтом

\begin{tabular}{|c|c|c|c|c|}
\hline Model & Factor & $B \pm S E$ & $\mathrm{z}$ & $P$ \\
\hline \multirow{5}{*}{ Number of plants visited } & Intercept & $-8.42 \pm 3.22$ & -2.62 & 0.009 \\
\hline & Temperature [linear] & $0.64 \pm 0.31$ & 2.03 & 0.043 \\
\hline & Temperature [quadratic] & $-0.01 \pm 0.01$ & -1.74 & 0.082 \\
\hline & Colour & $0.34 \pm 0.31$ & 1.11 & 0.265 \\
\hline & Number of open flowers & $0.01 \pm 0.01$ & 1.03 & 0.302 \\
\hline \multirow{5}{*}{ Number of flowers visited } & Intercept & $-14.99 \pm 4.27$ & -3.51 & $<0.001$ \\
\hline & Temperature [linear] & $1.26 \pm 0.42$ & 3.02 & 0.003 \\
\hline & Temperature [quadratic] & $-0.03 \pm 0.01$ & -2.75 & 0.006 \\
\hline & Colour & $0.87 \pm 0.38$ & 2.29 & 0.022 \\
\hline & Number of open flowers & $0.02 \pm 0.01$ & 3.14 & 0.002 \\
\hline
\end{tabular}



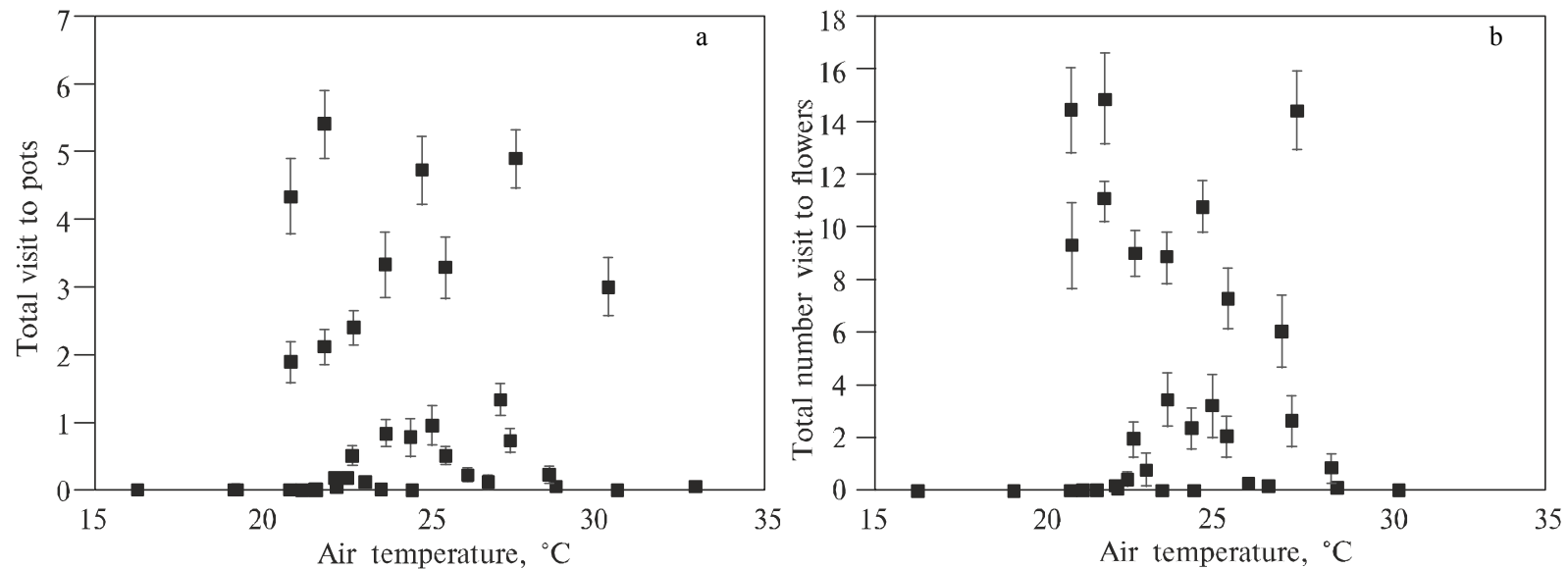

Fig. 1. Relationships between the temperatures registered in the greenhouse and [a] the total number of visits to pots and $[b]$ the total number of flowers visited per pot by Bombus terrestris. Points represent the mean \pm SE for each trial.

Рис. 1. Зависимость между температурами, зарегистрированными в теплиџе, и [а] общим числом посещений горшков с геранью, и [b] общим числом посешённых шмелями Bombus terrestris цветов в пересчёте на горшок. Точки отражают среднее значение \pm SE дмя каждого испытания.

Szczesna, 2008] and also in a wider range of bumblebee species [Lundberg 1980; Corbett et al., 1993]. In greenhouses, highest bumblebee foraging is around $25^{\circ} \mathrm{C}$ [Kwon, Saeed, 2003], similar to what we found.

Many pollinators exhibit bimodal patterns of foraging throughout the day, avoiding the highest temperatures [e.g. Herrera, 1990]. However, studies suggest this is not the case for B. terrestris [Peat et al., 2005; Couvillon et al., 2010]; declines in foraging rates may instead relate to a greater amount of time spent maintaining nest thermoregulation [Couvillon et al., 2010] or

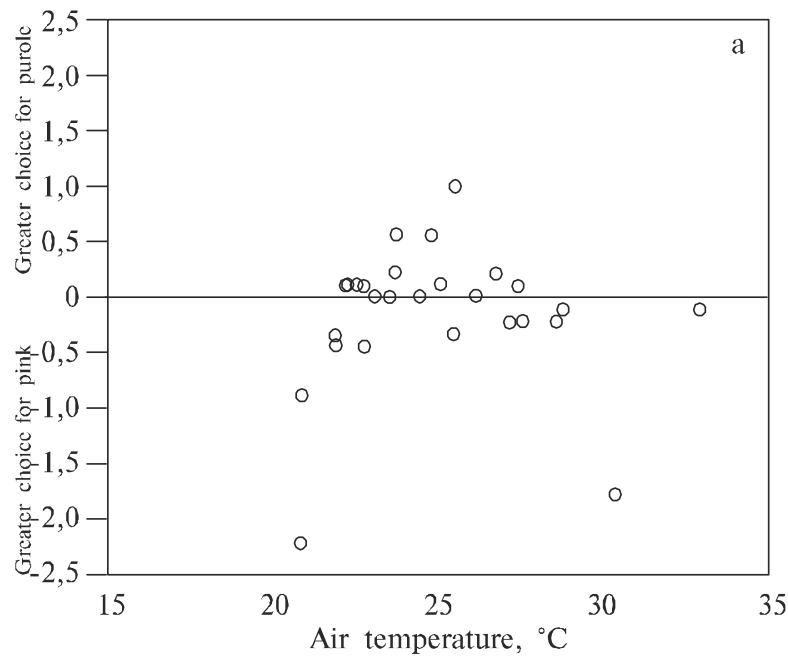

because of the increased nectar rewards available at higher temperatures [Corbet et al., 1979; Varga, Soulsbury, 2017]. Thus, patterns observed in foraging rate may stem from a number of potential reasons, but confirm the general pattern of temperature-dependent foraging in bumblebees.

Colour-dependent visitation rates. Our second major result was that foraging rates were related to the floral colour. Bumblebees preferred the dark morph over the pale morph both in the greenhouse and in the field, with increasing preference for dark morphs in the green-

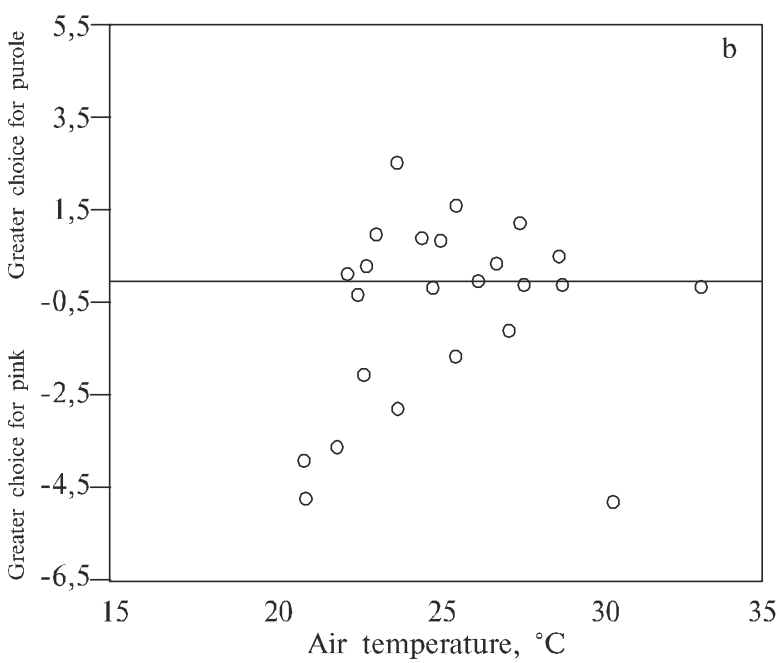

Fig. 2. Preference of Bombus terrestris visiting pale and dark colour morphs of Geranium sylvaticum in the greenhouse at different temperatures in [a] the total number of plants visited and [b] the total number of flowers visited per plant. Values $>0$ indicate a greater choice for dark morphs, values $<0$ indicate a greater choice for pale morphs. For clarity, we have removed trials with 0 visits. Each point represents the average differences between each morph within a trial.

Рис. 2. Предпочтение шмелями Bombus terrestris тёмных или бледных морф цветков герани Geranium sylvaticum в теплице при разных температурах, [a] - общее количество посешённых растений, [b] - общее количество посешённых цветов на одном растении. Значения $>0$ указывают на больший выбор дмя тёмных морф, значения $<0$ указывают на больший выбор Аля бледных морф. Аля ясности пробы с 0 посещениями не приводятся. КажАая точка преАставляет собой среАние различия межАу каждой морфой в ходе испытания. 
house at $23-26^{\circ} \mathrm{C}$. This was expected as bumblebees are reported to have an innate preference for this colour [Gumbert, 2000]. In addition, bumblebees will preferentially select for a greater quality nectar reward [Cnaani et al., 2006], and in G. sylvaticum, dark morphs have higher sugar content than pale morphs [Varga, Soulsbury, 2017]. Interestingly, selection for the dark morph was greatest during the "optimal" foraging temperature [i.e. $23-26^{\circ} \mathrm{C}$ ] in the greenhouse. Usually sugar concentration is increased at higher temperature levels [e.g. Petanidou, Smets, 1996] and even though most previous studies report no difference between colour morphs in sugar amount present in floral nectar [Galen, Kevan, 1980; Chen et al., 2014], we found dark morphs had higher sugar content than pale flowers in our study species and a positive relationship between sugar content and temperature [Varga, Soulsbury, 2017]. Hence, it is likely that the primary difference in foraging be-

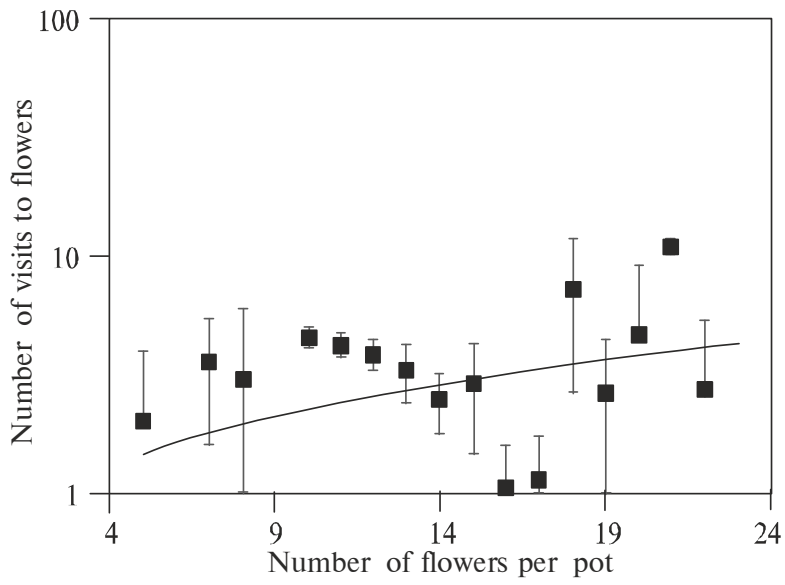

Fig 3. Relationship between the number of flowers visited and the number of open flowers (mean \pm SE) per pot.

Рис. 3. Связь межау количеством посещённых цветов и количеством открытых цветов (среднее \pm SE) на горшок.

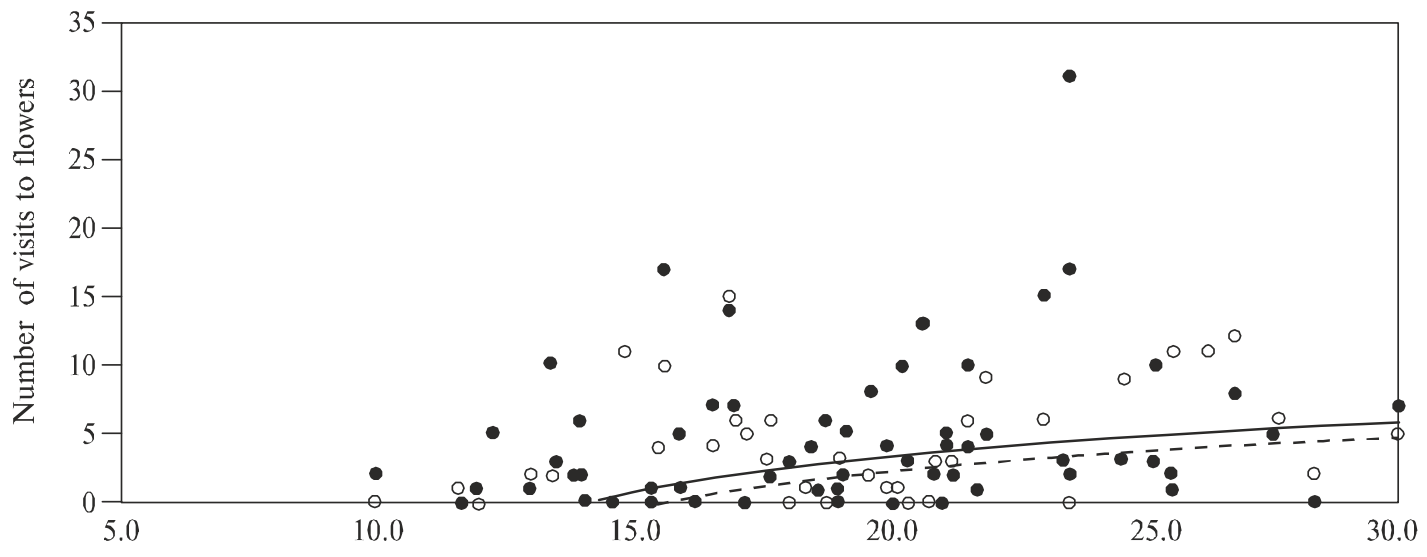

Air temperature, ${ }^{\circ} \mathrm{C}$

Fig. 4. Relationship between the temperatures registered in the field and the total number of flowers visited per plant by bumblebees for dark [filled circles, solid line] and pale [empty circles, dashed line] Geranium sylvaticum plants.

Рис. 4. Связь между температурой, отмеченной в поле, и общим количеством посещённых шмелями цветков на растение Geranium sylvaticum для тёмных [чёрные кружки, сплошная миния] и бледных [белые кружки, пунктирная миния] цветков герани.
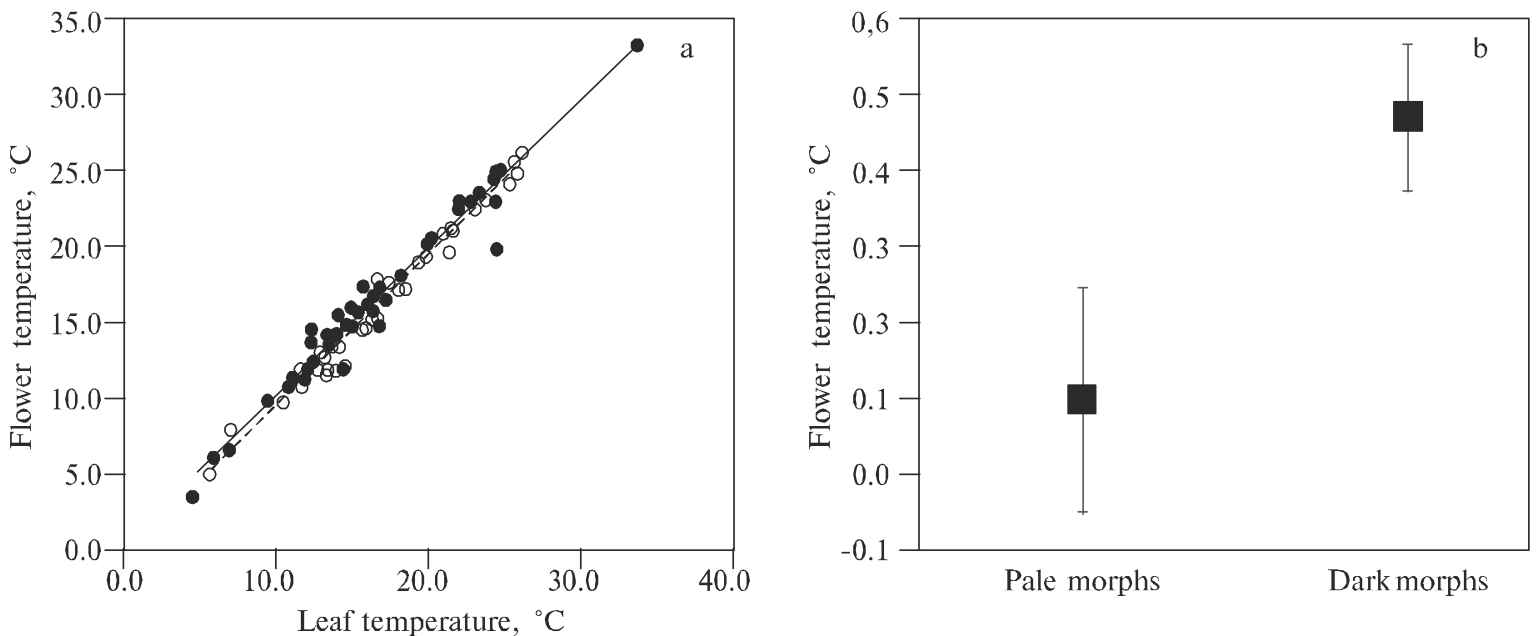

Fig. 5. Relationship between the [a] flower temperatures and leaf temperatures registered in the field for dark [filled circles, solid line] and pale [empty circles, dashed line] Geranium sylvaticum plants. Each data point is a separate plant. [b] The mean \pm SE difference between flower temperature and leaf temperature in pale dark morphs.

Рис. 5. Связь между температурой [а] цветков и Аистьев, отмеченной в поле для тёмных [чёрные кружки, сплошная миния] и бледных [белые кружки, пунктирная миния] цветков герани. Каждая точка данных представляет собой отдельное растение. $[\mathrm{b}]-$ среднее значение \pm SE между температурой цветка и температурой киста у бледных и тёмных морф. 
tween colours is driven by the reward quality. The lack of increasing preference in the field may simply derive from our smaller scale field work and the inability to control multiple confounding variables. Even so, our results show that both temperature and colour are important in floral choice for wild bumblebees. With increasing summer temperatures, the preference for darker morphs may lead to the longer term selection against the pale morph in northern climates.

\section{Acknowledgements}

The authors thank Hanna Nousiainen and Catriona Walker for collecting greenhouse data and the staff of Konnevesi Research Station supporting the practical work. CDS and SV designed the study, CDS and SV collected the data. Analysis and interpretation were done by CDS and SV. All authors draft the manuscript and read and approve the final submission. This study was financially supported by the Finnish Academy of Science [project number 250911] and Oskar Oflund Foundation to SV. The authors declare no conflict of interests.

\section{References}

Arista M., Talavera M., Berjano R., Ortiz P.L. 2013. Abiotic factors may explain the geographical distribution of flower colour morphs and the maintenance of colour polymorphism in the scarlet pimpernel // Journal of Ecology. Vol.101. No.6. P. 1613-1622.

Chen G., Gong W., Ge J., Dunn B.L., Sun W. 2014. Inflorescence scent, color, and nectar properties of «butterfly bush» (Buddleja davidii) in its native range // Flora. Vol.209. Nos 3-4. P.172-178.

Chittka L., Thomson J.D., Waser N.M. 1999. Flower constancy, insect psychology, and plant evolution // Naturwissenschaften. Vol.86. No.8. P.361-377.

Chittka L., Wells H. 2004. Color vision in bees: mechanisms, ecology and evolution. F. Prete (Ed). How simple nervous systems create complex perceptual worlds. MIT, Boston. P.165-191

Cnaani J., Thomson J.D. Papaj D.R. 2006. Flower choice and learning in foraging bumblebees: effects of variation in nectar volume and concentration // Etholology. Vol.112. No.3. P. 278-285.

Corbet S.A., Fussell M., Ake R., Fraser A., Gunson C., Savage A., Smith K. 1993. Temperature and the pollinating activity of social bees // Ecological Entomology. Vol.18. No.1. P.17-30.

Corbet S.A., Unwin D.M., Prys-Jones O.E. 1979. Humidity, nectar and insect visits to flowers, with special reference to Crataegus, Tilia and Echium // Ecological Entomology. Vol.4. No.1. P.9-22.

Couvillon M.J., Fitzpatrick G., Dornhaus A. 2010. Ambient air temperature does not predict whether small or large workers forage in bumble bees (Bombus impatiens) // Psyche. Article ID 536430 .

Durbin M.L., Lundy K.E., Morrell P.L., Torres-Martinez C.L., Clegg M.T. 2003. Genes that determine flower color: the role of regulatory changes in the evolution of phenotypic adaptations // Molecular Phylogenetics and Evolution. Vol.29 No.3. P.507-518.

Dyer A.G., Whitney H.M., Arnold S.E.J., Glover B.J., Chittka L. 2006. Bees associate warmth with floral colour // Nature. Vol.442. P.525.

Elgersma A., Stephenson A.G., Nijs A.P.M. 1989. Effects of genotype and temperature on pollen tube growth in perennial ryegrass (Lolium perenne L.) // Sexual Plant Reproduction. Vol.2. No.4. P.225-230.
Frey F.M. 2004. Opposing natural selection from herbivores and pathogens may maintain floral-color variation in Claytonia virginica Portulacaceae // Evolution. Vol.58. No.11. P.24262437.

Galen C., Kevan P.G. 1980. Scent and color, floral polymorphisms and pollination biology in Polemonium viscosum Nutt. // American Midland Naturalist. Vol.104. No.2. P.281-289.

Gegear R.J. 2005. Multicomponent floral signals elicit selective foraging in bumblebees // Naturwissenschaften. Vol.92. P.269271 .

Gigord L.D.B., Macnair M.R., Smithson A. 2001. Negative frequency-dependent selection maintains a dramatic flower color polymorphism in the rewardless orchid Dactylorhiza sambucina L. // Proceedings of the National Academy of Science of the United States of America.Vol.98. P.62536255 .

Giurfa M., Nunez J.A., Chittka L., Menzel R. 1995. Colour preferences of flower-naive honeybees // Journal of Comparative Physiology A. Vol.177. No.3. P.247-259.

Gould K.S. 2004. Nature's Swiss army knife: the diverse protective roles of anthocyanins in leaves // Journal of Biomedicine and Biotechnology. Vol.2004. No.5. P.314-320.

Goulson D. 2010. Bumblebees: behaviour, ecology, and conservation. Oxford University Press, USA. 336 p.

Gumbert A. 2000. Color choices by bumble bees Bombus terrestris: innate preferences and generalizations after learning // Behavioral Ecology, Sociobiology. Vol.48. No.1. P.36-43.

Heinrich B. 1979. Bumblebee Economics. Harvard University Press, Cambridge, MA. 288 p.

Herrera C.M. 1990. Daily patterns of pollinator activity, differential pollinating effectiveness, and floral resource availability, in a summer-flowering Mediterranean shrub // Oikos. Vol.58. No.3. P.277-288.

Herrera C.M. 1995. Microclimate and individual variation in pollinators: flowering plants are more than their flowers // Ecology. Vol.76. No.5. P.1516-1524.

Hulten E., Fries M. 1986. Atlas of North European vascular plants north of the tropic of Cancer. I-III. Koeltz, Konigtein. 1172 p.

Irwin R.E., Strauss S.Y., Storz S., Emerson A., Guibert G. 2003. The role of herbivores in the maintenance of a flower color polymorphism in wild radish // Ecology. Vol.84. No.7. P.1733-1743.

Jakobsen H.B., Kristjansson K. 1994. Influence of temperature and floret age on nectar secretion in Trifolium repens L. // Annals of Botany. Vol.74. No.4. P.327-334.

Kevan P., Giurfa M., Chittka L. 1996. Why are there so many and so few white flowers? // Trends in Plant Science. Vol.1. No.8. P.280-284.

Kitaoka T.K., Nieh J.C. 2009. Bumble bee pollen foraging regulation: role of pollen quality, storage levels, and odor // Behavioral Ecology, Sociobiology. Vol.63. No.4. P.501-510.

Koski M.H., Ashman T.-L. 2015. Floral pigmentation patterns provide an example of Gloger's rule in plants // Nature Plant. Vol.1. P.14007.

Kuznetsova A., Brockhoff P.B., Christensen R. 2014. ImerTest: tests in liner mixed effects models. R-package v2.0-20.

Kwon Y.J., Saeed S. 2003. Effect of temperature on the foraging activity of Bombus terrestris L. (Hymenoptera: Apidae) on greenhouse hot pepper Capsicum annuum L. // Applied Entomology and Zoology. Vol.383. P.275-280.

Lunau K., Maier E.J. 1995. Innate colour preferences of flower visitors // Journal of Comparative Physiology A. Vol.177. No.1. P.1-19.

Lundberg H. 1980. Effects of weather on foraging-flights of bumblebees Hymenoptera, Apidae in a subalpine/alpine area // Ecography. Vol.3. No.2. P.104-110.

McKee J., Richards A.J. 1998. Effect of flower structure and flower color on intrafloral warming and pollen germination and pollen-tube growth in winter flowering Crocus L. (Iridaceae) // Botanical Journal of the Linnean Society. Vol.128. P.369-384. 
Mu J., Li G., Sun S. 2010. Petal color, flower temperature, and behavior in an alpine annual herb, Gentiana leucomelaena (Gentianaceae) // Arctic, Antarctic, and Alpine Research. Vol.42. No.2. P.219-226.

Mu J., Li G., Niklas K.J., Sun S. 2011. Difference in floral traits, pollination, and reproductive success between white and blue flowers of Gentiana leucomelaena (Gentianaceae) in an Alpine Meadow // Arctic, Antarctic, and Alpine Research. Vol.43. No.3. P.410-416.

Nicolson S.W., De Veer L., Kohler A., Pirk C.W. 2013. Honeybees prefer warmer nectar and less viscous nectar, regardless of sugar concentration // Proceedings of the Royal Society B. Vol.280. P.20131597.

Peat J., Darvill B., Ellis J., Goulson D. 2005. Effects of climate on intra and interspecific size variation in bumblebees // Functional Ecology. Vol.19. No.1. P.145-151.

Peat J., Goulson D. 2005. Effects of experience and weather on foraging rate and pollen versus nectar collection in the bumblebee, Bombus terrestris // Behavioral Ecology, Sociobiology. Vol.58. P.152-156.

Peitsch D., Fietz A., Hertel H., de Souza J., Ventura D.F., Menzel R. 1992. The spectral input system of hymenopteran insects and their receptor-based colour vision // Journal of Comparative Physiology A. Vol.170. P.23-40.

Petanidou T., Smets E. 1996. Does temperature stress induce nectar secretion in Mediterranean plants? // New Phytologist. Vol.133. No.3. P.513-518.

Quattrocchio F., Wing J., van der Woude S.E., de Vetten N., Mol J., Koes R. 1999. Molecular analysis of the anthocyanin2 gene of Petunia and its role in the evolutioin of flower color // Plant Cell. Vol.11. P.1433-1444.

R-Core Team. 2015. R: A language and environment for statistical computing. R Foundation for Statistical Computing, Vienna, Austria. http://www.R-project.org.

Rausher M.D. 2008. Evolutionary transitions in floral color // International Journal of Plant Sciences. Vol.169. P.7-21.

Roman A., Szczesna N. 2008. Assessment of the flying activity of the buff-tailed bumblebee Bombus terrestris L. on greenhouse-grown tomatoes // Journal of Apicultural. Science. Vol.52. P.93-101.
Schemske D.W., Bierzychudek P. 2001. Perspective: Evolution of flower color in the desert annual Linanthus parryae: Wright revisited // Evolution. Vol.55. No.7. P.12691282 .

Schemske D.W., Bierzychudek P. 2007. Spatial differentiation for flower color in the desert annual Linanthus parryae: was Wright right? // Evolution. Vol.61. P.2528-2543.

Stelzer R.J., Chittka L., Ings T.C. 2010. Winter active bumblebees (Bombus terrestris) achieve high foraging rates in urban Britain // PLoS One. Vol.5. P.e9559.

Strauss S.Y., Whittall J.B. 2007. Non-pollinator agents of selection on floral traits. L.D. Harder, S.C.H. Barrett (Eds): Ecology and evolution of flowers. Oxford University Press, Oxford. P.120-138.

Vaarama A., Jaaskelainen O. 1967. Studies on gynodioecism in the Finnish populations of Geranium sylvaticum L. // Annales Academiae Scientiarum Fennica Series A: IV Biology. Vol.108. P. $1-37$.

Varga S., Kytoviita M.-M. 2010. Gender dimorphism and mycorrhizal symbiosis affect floral visitors and reproductive output in Geranium sylvaticum // Functional Ecology. Vol.24. No.4. P.750-758.

Varga S., Soulsbury C.D. 2017. Sexually-trimorphic interactions with colour polymorphism determine nectar quality in a herbaceous perennial // Scientific Reports. Vol.7. P.45838.

Venables W.N., Ripley B.D. 2002. Modern applied statistics with S. Fourth Edition. Springer, New York. 495 p.

Warren J., MacKenzie S. 2001. Why are all colour combinations not equally represented as flower-colour polymorphisms? // New Phytologist. Vol.151. No.1. P.237-241.

Waser N.M., Price M.V. 1983. Pollinator behaviour and natural selection for flower colour in Delphinium nelsonii // Nature. Vol.302. P.422-424.

Willmer P. 2011. Pollination and floral ecology. Princeton University Press. 832 p.

Willmer P.G., Stone G.N. 2004. Behavioral, ecological, and physiological determinants of the activity patterns of bees // Advances in the Study of Behaviour. Vol.34. P.347466. 